\title{
The influence of changes in Land Use/Land Cover (LULC) on Land Surface Temperature in Ramanathapuram coast and Assessment of Urban Heat Island, using remote sensing and GIS
}

Gurugnanam Balsubramanian ( $\sim$ gurugis4u@gmail.com )

The Gandhigram Rural Institute Deemed University https://orcid.org/0000-0002-8775-7123

\section{Glitson Francis Pereira}

The Gandhigram Rural Institute - Deemed to be University

\section{Bairavi Swaminathan}

The Gandhigram Rural Institute - Deemed to be University

\section{Santonu Goswami}

Scientist -G ,National Remote Sensing Centre

Saroj B Choudhury

Scientist -National Remote Sensing Centre

\section{Research Article}

Keywords: Land use/landcover, Land surface temperature, Geographic Information System, Urban heat island, Contribution Index

Posted Date: July 19th, 2021

DOl: https://doi.org/10.21203/rs.3.rs-702366/v1

License: (a) (i) This work is licensed under a Creative Commons Attribution 4.0 International License. Read Full License 


\section{Abstract}

Due to marine and terrestrial processes, the land use/land cover features of the Ramanathapuram coastal area noticed dynamic changes. Sometimes the anthropogenic activities and nature also governed such changes. Landuse/Landcover analysis is an essential parameter for the climate change studies in coastal region. Similarly, the analysis of land surface temperature (LST) and the severity of Urban heat island (UHI) also factored for assessing its influence on climate changes. In this study, Remote sensed Landsat satellite data from 2000 to 2020 is very well used to identify the relation between LULC and LST. Advance tools in GIS (Geographic Information Systems) softwares is used to integrate the results. The findings strongly indicate that the built-up area is increasing every year. In the year 2000 , the build-ups are noted with $8 \mathrm{~km}^{2}$, and it was increased to $44 \mathrm{~km}^{2}$ in 2020. In addition, the LST of the year 2000, 2005, 2010, 2015, and 2020 radiates a maximum temperature of about $30^{\circ} \mathrm{C}, 29^{\circ} \mathrm{C}, 30^{\circ} \mathrm{C}, 30^{\circ} \mathrm{C}$, and $27^{\circ} \mathrm{C}$, respectively. The highest radiance temperature is observed in barren land; the $\mathrm{UHI}$ analysis also points towards increased urban activities. The temperature is comparatively high in an urbanised area, and its UHI values range from very Strong to moderate heat island.

\section{Introduction}

Land use / Land cover has an regular impact on the climatic condition. Since the climatic condition has changed and human influence, there has been a change in the coastal environment (Velsamy, S et al., 2020). Analysing Land use-land cover for several decades is an excellent method to figure out the changes on the land surface. The significance of studying LULC and its consequences are essential for natural resource planning and sustainable environmental management (Lambin et al., 2000; Read and Lam et al., 2002). Coastal dynamics impact a variety of physical, climatic, and biological aspects (Nithu Raj et al.2019). Recent analyses using geospatial techniques are pretty beneficial for analysing various spatial changes in the land surface. The ability of satellite-based data is now a commonly accepted tool for LULC mapping (Saadat et al. 2011; Yuan et al. 2005; Herold et al. 2003; Lambin et al. 2003; Hathout et al. 2002). In the last few decades, geospatial technology has been used for LULC mapping and climate change research. (Wu et al. 2018; Lv et al. 2018; Jin et al. 2017; Sekertekin et al. 2017; Phiri and Morgenroth et al. 2017). The gradual change of the landscape through various forms of land usage is seen worldwide (Geist et al. 2001). Land use/coverage is also dictated by environmental factors, elevation, geographical structure, slope, socioeconomic, and technological context, which often influences land-use trends (Rai et al. 1994). Urbanisation, Population growth and industrialisation, and have a rapid impact on LULC (Voogt et al. 2003). LULC has a significant role in environmental transition (Lambin et al. 1999). Natural ecosystems will be disrupted, including biodiversity, water, and radiation budgets. (Guzha et al. 2018; Kiruki et al. 2017; Yang et al. 2017; Lambin and Meyfroidt 2011; Riebsame et al. 1994).

LST is a significant climatic variable for estimating decadal climate variations. It is a strong indicator for understanding surface temperature (Schneider and Hook, 2010). The LST details are used for various atmospheric studies (Dousset et al., 2011; Luvall et al., 2015). The LST analysis was helpful to understand the influence of greenhouse gases, which tend to raise the temperature and the chances to melt polar ice caps. It will be increasing sea levels and floods. The radical changes in LST are due to the shift in rainfall 
pattern, which affects the entire surface of the vegetation (Rajeshwari et al., 2014). Urban climate, evaporation, hydrology and vegetation analysis are just a few of the applications for LST (Hansen et al. 2010; Kalma et al. 2008; Weng et al. 2004; Arnfield, 2003; Su et al. 2002; Kogan et al. 2001; Bastiaanssen et al. 1998). The radiative temperature from the earth reflecting radiative energy is known as land surface temperature. It will help to understand the temperature fluctuation on the land. it's commonly used to monitor droughts. (Anderson et al., 2011; Hain et al., 2011). The reflecting radiance of each surface feature is different. So, LULC and its changes are highly influencing the land surface temperature. Various Natural and anthropological factors tend to change in the LULC of an area. As it changes, the climate of the region will also show variations. As a result, the study is receiving more attention these days for quantifying the magnitude of the LST on a regional basis. (Norman and Becker et al.1995). Remote sensing satellite data is widely used these days for LST estimation using thermal data (Rajeshwari et al., 2014). Now, due to the free availability of the data, the usage of this data type is increased.

The term "urban heat island" refers to a region where noticeably higher temperature than the surrounding areas due to human influences. The temperature in an urban area is substantially greater than in an underdeveloped or rural area nearby. Nowadays, construction activities have increased demand for residential, commercial, and industrial purposes (Buyadi et al., 2013). During 1950, only 30\% population lived in urban areas (Essa et al. 2012). According to India's 2011 census, the country's urban population has grown dramatically in the recent two decades (Pandey \& Seto et I. 2015). The percentage of people living in cities has increased significantly. Between 2010 and 2050, India's urban population is expected to grow by more than 500 million people, according to UN estimates. The growth of the city's population compelled the area's construction to expand. Hence it will damage the vegetation cover in the land for making the structures to urbanisation. It leads to increased structured sites and decreased green cover in cities (Rahman et al. 2013; Rahman et al. 2012; Shahmohamad et al. 2011; Rahman et al., 2007). Urbanisation will transforms vegetation into a structured area and mainly within the boundaries of the agricultural land surrounding them (Pandey \& Seto, 2015). The temperature of the land surface will rise if vegetation is reduced and barren land is increased. (Kumar et al. 2012).

The city's climate is influenced by the green thermal system, which improves selective absorption and reflection of incident radiation while also managing latent and reactive heat transfer (Owen et al. 1998; Nichol et al. 1996; Gallo et al. 1995; Carlson et al. 1994). Vegetation is an essential part of the world and has a multidimensional role across all the physical elements (Rao \& Puntambekar et al., 2011). Green space is a must-have in any city since it contributes to a healthy urban environment and a healthy way of life. It will keep the urban regions' natural and environmental attractiveness (Chen et al. 2006). The Green vegetation in the earth improves the quality of air and reduces biodiversity conservation. It will reduce the violence of UHI and a significant contributor to environmental sustainability (Senanayake et al. 2013; Colding et al. 2007; Kühn et al. 2006; Gaston et al. 2005; Pauleit et al. 2000; Bolund et al. 1999). The increase in urban heat island $(\mathrm{UHI})$ in metropolitan regions is caused by a reduction in plant cover and an increase in the built-up part, resulting in a degradation of the environmental condition in industrial areas (Mallick et al. 2013). Earth's surface temperature influences the planet's physical, chemical, and biological properties (Becker et al., 1990). The relationship between built-up land, vegetation cover, and the LST was investigated by (Badarinath et al. 
2005). Several studies have found a clear link between LST, built-up, and green cover as a result of urbanisation. (Kumaret al. 2012; Weng et al. 2004).

Landsat satellite data is beneficial to analyse the historical and recent changes in different types of land cover, (Galford et al. 2008; Seto et al. 2002; Woodcock et al. 2001; Coppin et al.1996; Jensen et al. 1995). Its spatial and spectral coverage has continuous measurement up to the near-nadir (Woodcock \& Strahler et al., 1987).

\section{Materials And Methods 2.1 Study Area}

Ramanathapuram coastal part of Tamil Nadu, India's coastline region has taken for the study. It is situated between the geographic coordinate's $78^{\circ} 45^{\prime} \mathrm{E}$ and $79^{\circ} 20^{\prime} \mathrm{E}$ longitudes, as well as the latitudes of $9^{\circ} 05^{\prime} \mathrm{N}$ and $9^{\circ} 30^{\prime} \mathrm{N}$, at 3 meters above mean sea level. There are 21 unpopulated coral islands situated within a $10 \mathrm{~km}$ radius from the coastal belt of Ramanathapuram. More than 30,000 fishermen live in this area, and various large- and small-scale industries present for the economic sustain of people. The study has carried out in a $468 \mathrm{~km}^{2}$ area, over the coastal villages viz. Kalimankund, Ervadi, Mayakulam, Keelakarai, Kanjirangudi, Periapattinam, Karan, Rettaiyurani, Pudumadam, Tiruppulani,Nochiyurani, Sattakonvalsai, Enmanamkondan, Nagachi, Attangarai, Alagankulam, Terbhogi, Pirappanvalsai Athyuthu, Chitrakkottai, Devipattinam, Pathanendal, Mandapam, Pamban, and Rameswaram (Fig. 1).

\subsection{Data Used}

Landsat (OLI, ETM+, and TM) was used to figure out LULC, LST, and UHI mapping. It helps in the detection of changes in the research area. Landsat-7 ETM + and Landsat-4 TM images have $60 \mathrm{~m}$ spatial resolution, while Landsat-8 have a spatial resolution of $30 \mathrm{~m}$. The data was taken from the website of USGS Earth Explorer. The satellite data taken for the study are precise and practically cloud-free. To map LULC from remotely sensed digital data, a supervised digital image classification technique can be applied. (Thomas et al., 1987; Campbell et al., 1987). Visual analysis and supervised classification are carried out using the falsecolour composite (FCC) during the investigation. The Thermal Infrared (TIR) of the Landsat satellite data series is highly useful for estimating ground radiative energy using the Radiative Transfer Equation (RTE).

\subsection{Image Processing and Classification}

Data accuracy is fundamental for mapping and identifying the changes in the land surface. Every satellite data contains both radiometric and geometric errors. Correction of these errors is essential for the generation of the data with significant levels of location precision. The data were taken to GIS using an input tool. The multi-date Landsat satellite and the Toposheets were taken to GIS. Image pre-processing methods in GIS platforms. The registration of data, geometric and radiometric calibration were used to process the data. These methods help reduce data errors and enhance the quality of the spatial data. The multi-date satellite data retrieved were pre-processed using techniques for enhancing the images. This includes strip detection and restorement, image processing, and topographical correction. When using distinct ancillary data of 
different sources or formats, evaluation is essential before integrating it into a classification procedure. Multiple source data needs strong data rectification for a classification algorithm. Digital images were processed and co-registration is done to standardise data using ERDAS image processing software. LULC mapping is an image classification method in remote sensing. It categorises the land feature based on the pixel values of satellite data. The study helps to identify the physiographic changes and able to predict hazardous regions.

Landsat imagery (TM, ETM+, and OLI) used for LULC mapping of the year 2000, 2005, 2010, 2015, and 2020 to identifying changes in the study region. LULC can mapped from digital satellite data through a supervised image classification process (Campbell et al. 1987; Thomas et al. 1987). Visual analysis and supervised classification are carried out using the false-colour composite (FCC) during the analysis. Image classification technique in GIS software, usually pair all similar pixels in an image into land cover groups (Kiefer et al. 1994). The maximum likelihood classifier calculates the variance and covariance of the spectral response patterns in the category while categorising an unknown pixel. As a result of its statistical properties, it is regarded as one of the most accurate image classifiers. The study area is classified into Ten main classes (Table 1): Water bodies, Saltpan, Plantation, Sand/ Sandy beaches, Barren land, Mangrove, Shrubland, Lagoon, Tidal Flat, and Built-up Land.

Table 1

Land use and Land cover classifications and Description

\section{SI. Land Use Description
Type \\ No}

1 Plantations Commercial horticulture plantations, orchards and tree cash crops 2 Built-up Land covered with buildings and other man-made structures

3 Water Areas with surface water, either impounded in the form of ponds, lakes, reservoirs or bodies flowing as streams, rivers, etc. Can be either fresh or salt-water bodies

4 Mangrove Evergreen forests in the intertidal areas. These forests are dense and dominated by halophytic plants

5 Sand/

Sandy

White colour sand deposited and beach sediments

Beaches

6 Salt Pan Land covered with salt and minerals

7 Barren land Exposed soil, sand, rocks, or snow and never have more than 10\% vegetated cover during any time of the year

8 Shrubland Zone of soft, moist land, intermittently or permanently filled by sand and mud, mostly vegetated by shrubs and trees,

9 Lagoons Shallow region of waterbody separated from sea

10 Tidal Flat Intertidal zones where sediments accumulated by tidal action 
The Thermal Infrared (TIR) satellite data collection from Landsat is extremely valuable for estimating ground radiative energy using the Radiative Transfer Equation. The research area's land surface temperature is calculated using a thermal infrared band. Climate Change, Evapotranspiration, Hydrological Cycle, Vegetation, Urban Atmosphere, and Natural Investigation Assessment are just a few examples of applications where LST is commonly used. (Hansen et al. 2010; Weng, 2009; Kalma et al. 2008; Weng et al. 2004; Arnfield et I. 2003; Voogt et al. 2003; Kogan, 2001; Bastiaanssen et al. 1998). Land surface temperature (LST) is one of the essential elements influence by surface energy (Karnieli et al. 2010; Kustas et al. 2009; Anderson et al. 2008; Zhang et al. 2008; Brunsell et al. 2003).

\subsection{Accuracy Assessment}

Accuracy is an essential for LULC classification process. It decides whether the reference data and categorised data are acceptable. (Tso et al. 2005). The accuracy assessment is done with 50 field-collected ground truth locations. Then it has validated with the classified result of land use/land cover 2000, 2005, 2010, 2015, and 2020 in ArcGIS. Finally the similarity has been determined between ground truth locations and land use / landcover classes.

\subsection{Retrieval of Brightness Temperature 2.5.1 Conversion of DN - Radiance}

The pixel values in a satellite data dependent on its resolution, are referred to as DN. It conveys information regarding the spectral reflectance of the object. The primary stage in performing a fine spectral analysis for the study is to convert DN values into spectral radiance using the following computation.

$L_{\lambda}=M_{L} \times Q_{\text {cal }}+A_{L}-O_{i}$,

Here, $M_{L}$ is the multiplicative rescaling factor for each band, $Q_{\text {cal }}$ is Band 10 in an image, $A_{L}$ is the additive rescaling factor for each band., and $O_{i}$ is Band 10 correction (Barsi et al. 2014).

\subsubsection{Conversion- Radiance to At-Sensor Temperature}

It involves converting Digital Numbers (DN) into reflection in terms of brightness. The TIRS band is converted from the spectral radiation to brightness temperature (BT) using the following equation,

$$
B T=\frac{K_{2}}{\ln \left[\frac{K_{1}}{L_{\lambda}}+1\right]}
$$

Here BT is effective while calculating satellite temperature in Kelvin for obtaining the results in Celsius, $\mathrm{K}_{1}$ and $\mathrm{K}_{2}$ are calibration constants, and $L_{\lambda}$ is spectral Radiance (USGS, 2013).

\subsection{Urban Heat Island Intensity}

To determine the Urban Heat Island, the relative radiative temperature was calculated using the land surface temperature as the average for each year. The formula used for the calculation of UHI is given below (Xu et al. 2013; Zhang et al. 2012) 


$$
\mathrm{UHI}_{n}=\frac{\mathrm{T}_{n}-\mathrm{T}_{\text {mean }, 2000}}{\mathrm{~T}_{\text {mean }, 2000}}
$$

Where,

$\mathrm{UHI}$ is Urban Heat Island in the year (n),

$T_{n}$ is the temperature of the year (n).

$T_{\text {mean }}$ is the land surface temperature of the year 2000

UHI was categorised as Green Island (UHI Range >0), Weak heat island (UHI Range 0-0.005), Strong heat island (UHI Range 0.005-0.010), Stronger heat island (UHI Range 0.010-0.015), Strongest heat island (UHI Range $0.015-0.020)$, Violent heat island $(>0.020)$

\section{Results And Discussion}

\subsection{Land use/Land cover Changes 2000 and 2020}

The analysis was carried out for 2000, 2005, 2010, 2015, and 2020. There are 10 number of land use-land cover classes are observed and classified: Built-up Land, Plantation, Barren land, Sand/ Sandy Beaches, Water bodies, mangroves, Saltpan, Scrubland, lagoon, and Tidal flat. The results are given in (Table 2), and spatial maps are given in Fig. 2 (a-e).

Table 2

Land Use and Land Cover Changes between 2000 and 2020

\begin{tabular}{|llllll|}
\hline Classes & $\mathbf{2 0 0 0}$ & $\mathbf{2 0 0 5}$ & $\mathbf{2 0 1 0}$ & $\mathbf{2 0 1 5}$ & $\mathbf{2 0 2 0}$ \\
\cline { 2 - 5 } & Area $\mathbf{~ k m}^{2}$ & Area $\mathbf{~ k m}^{2}$ & Area $\mathbf{~ k m}^{2}$ & Area $\mathbf{~ k m}^{2}$ & Area km \\
\hline Built-up Land & 8 & 19 & 31 & 35 & 44 \\
\hline Plantation & 67 & 89 & 68 & 68 & 73 \\
\hline Barren land & 201 & 162 & 218 & 220 & 222 \\
\hline Sand/ Sandy Beaches & 127 & 145 & 85 & 85 & 82 \\
\hline Water bodies & 16 & 15 & 23 & 23 & 21 \\
\hline Mangrove & 1 & 1 & 0.8 & 0.97 & 0.5 \\
\hline Saltpan & 1 & 2 & 3 & 3 & 7 \\
\hline Shrubland & 12 & 11 & 13 & 12 & 9 \\
\hline lagoon & 16 & 12 & 14 & 14 & 13 \\
\hline Tidal flat & 1 & 1 & 1 & 1 & 1 \\
\hline
\end{tabular}


An overall result shows that Barren land is highly dominated class in the area. The northern and southern area is coastal region. So, sand/sandy beaches become the Second dominantly occupied landcover feature. The sand/sandy beaches become decreased from $127 \mathrm{~km}^{2}$ in 2000 to $82 \mathrm{~km}^{2}$ in 2020 . The third dominant one is Plantations. The plantation was increased from $67 \mathrm{~km}^{2}$ in 2000 to $73 \mathrm{~km}^{2}$ in 2020 . It covered near the Vaigai river basin. Plantain and coconut trees are mostly cultivated in the region-the residential area primarily dominated in the central part of Rameswaram island. The residence is increasing every year. During the year 2000, the build-ups are noticed with $8 \mathrm{~km}^{2}$. While in 2020, the area covered with $44 \mathrm{~km}^{2}$ of built-up land. The Saltpans increased from $1 \mathrm{~km}^{2}$ in 2000 to $7 \mathrm{~km}^{2}$ in 2020. It is mainly seen in the northern corner of Rameswaram island and near the coastal region of Sethuhukarai and Atangarai villages. The area of water bodies increased from $16 \mathrm{~km}^{2}$ in 2000 to $21 \mathrm{~km}^{2}$ in 2020 . However, Shrubland decreased from $12 \mathrm{~km}^{2}$ in 2000 to $9 \mathrm{~km}^{2}$ in 2020. Similarly, Mangroves in this region fell from $1 \mathrm{~km}^{2}$ in 2000 to $0.5 \mathrm{~km}^{2}$ in 2020 . Mangroves are mostly covered in the Devipatinam region.

The degree of acceptance between reference data and classified data is tested during accuracy evaluation, an important aspect of the image classification procedure. The land use and land cover accuracy studies were carried out for the ten classes with 50 ground control locations for each class (500 points). In the year 2000 , the results show an overall accuracy of $90 \%$ and Kappa coefficient of $89 \%$. It seems the higher amount of matching with classified map and ground location is shown in (Table 3). The user's accuracy of $89 \%$ was noticed for Barren Land (BL), 90\% for Built-up Land (Bu), 75\% for Lagoon (La), 100\% for mangroves (Ma), $89 \%$ for Plantation (PI), $100 \%$ for Salt pan, $100 \%$ for Sand /sandy beaches, $73 \%$ for Shrub Land, $100 \%$ for Tidal Flats and $100 \%$ for water bodies. 
Table 3

Accuracy Assessment of Land Use and Land Cover_ 2000

\begin{tabular}{|c|c|c|c|c|c|c|c|c|c|c|c|c|}
\hline Class & $\mathrm{BL}$ & $\mathrm{Bu}$ & $\mathrm{La}$ & $\mathrm{Ma}$ & PI & Sp & SB & SL & TF & WB & Total & $\begin{array}{l}\text { User's } \\
\text { Accuracy } \\
\text { (\%) }\end{array}$ \\
\hline BL & 8 & 0 & 0 & 0 & 1 & 0 & 0 & 0 & 0 & 0 & 9 & 89 \\
\hline $\mathrm{Bu}$ & 0 & 9 & 0 & 0 & 0 & 0 & 0 & 1 & 0 & 0 & 10 & 90 \\
\hline La & 1 & 0 & 9 & 1 & 0 & 0 & 0 & 0 & 1 & 0 & 12 & 75 \\
\hline $\mathrm{Ma}$ & 0 & 0 & 0 & 8 & 0 & 0 & 0 & 0 & 0 & 0 & 8 & 100 \\
\hline PI & 0 & 1 & 0 & 0 & 8 & 0 & 0 & 0 & 0 & 0 & 9 & 89 \\
\hline Sp & 0 & 0 & 0 & 0 & 0 & 8 & 0 & 0 & 0 & 0 & 8 & 100 \\
\hline SB & 0 & 0 & 0 & 0 & 0 & 0 & 9 & 0 & 0 & 0 & 9 & 100 \\
\hline SL & 1 & 0 & 1 & 0 & 0 & 0 & 0 & 8 & 0 & 1 & 11 & 73 \\
\hline TF & 0 & 0 & 0 & 0 & 0 & 0 & 0 & 0 & 9 & 0 & 9 & 100 \\
\hline WB & 0 & 0 & 0 & 0 & 0 & 0 & 0 & 0 & 0 & 9 & 9 & 100 \\
\hline Total & 10 & 10 & 10 & 9 & 9 & 8 & 9 & 9 & 10 & 10 & 85 & \\
\hline $\begin{array}{l}\text { Producer's } \\
\text { Accuracy (\%) }\end{array}$ & 80 & 90 & 90 & 89 & 89 & 100 & 100 & 89 & 90 & 90 & & \\
\hline \multicolumn{13}{|c|}{ Overall Accuracy $=90 \%$} \\
\hline Kappa coeffic & & & & & & & & & & & & \\
\hline
\end{tabular}

Accuracy assessment for the year 2005 results in an overall accuracy of 94\%, Kappa coefficient of $93 \%$ (Table 4). The user's accuracy of $82 \%$ was noticed for Barren Land (BL), $91 \%$ for Built-up Land (Bu), $100 \%$ for Lagoon (La), 100\% for mangroves (Ma), 100 \% for Plantation (PI), 89\% for Salt pan, 100\% for Sand /sandy beaches, $90 \%$ for Shrub Land, $100 \%$ for Tidal Flats and $90 \%$ for water bodies. 
Table 4

Accuracy Assessment of Land Use and Land Cover_ 2005

\begin{tabular}{|c|c|c|c|c|c|c|c|c|c|c|c|c|}
\hline Class & $B L$ & $\mathrm{Bu}$ & La & $\mathrm{Ma}$ & $\mathrm{PI}$ & Sp & SB & SL & TF & WB & Total & $\begin{array}{l}\text { User's } \\
\text { Accuracy } \\
\text { (\%) }\end{array}$ \\
\hline $\mathrm{BL}$ & 9 & 0 & 1 & 0 & 0 & 0 & 0 & 1 & 0 & 0 & 11 & 82 \\
\hline $\mathrm{Bu}$ & 0 & 10 & 0 & 0 & 1 & 0 & 0 & 0 & 0 & 0 & 11 & 91 \\
\hline La & 0 & 0 & 8 & 0 & 0 & 0 & 0 & 0 & 0 & 0 & 8 & 100 \\
\hline Ma & 0 & 0 & 0 & 8 & 0 & 0 & 0 & 0 & 0 & 0 & 8 & 100 \\
\hline PI & 0 & 0 & 0 & 0 & 9 & 0 & 0 & 0 & 0 & 0 & 9 & 100 \\
\hline Sp & 0 & 0 & 0 & 1 & 0 & 8 & 0 & 0 & 0 & 0 & 9 & 89 \\
\hline SB & 0 & 0 & 0 & 0 & 0 & 0 & 9 & 0 & 0 & 0 & 9 & 100 \\
\hline SL & 0 & 0 & 0 & 0 & 0 & 0 & 0 & 9 & 0 & 1 & 10 & 90 \\
\hline TF & 0 & 0 & 0 & 0 & 0 & 0 & 0 & 0 & 9 & 0 & 9 & 100 \\
\hline WB & 0 & 0 & 0 & 1 & 0 & 0 & 0 & 0 & 0 & 9 & 10 & 90 \\
\hline Total & 9 & 10 & 9 & 10 & 10 & 8 & 9 & 10 & 9 & 10 & 88 & \\
\hline $\begin{array}{l}\text { Producer's } \\
\text { Accuracy } \\
\text { (\%) }\end{array}$ & 100 & 100 & 88.8889 & 80 & 90 & 100 & 100 & 90 & 100 & 90 & & \\
\hline \multicolumn{13}{|c|}{ Overall Accuracy = $94 \%$} \\
\hline \multicolumn{13}{|c|}{ Kappa coefficient $=93 \%$} \\
\hline
\end{tabular}

Accuracy assessment for the year 2010 results in an overall accuracy of 95\%, Kappa coefficient of $94 \%$

(Table 5). The user's accuracy of $90 \%$ was noticed for Barren Land (BL), $100 \%$ for Built-up Land (Bu), $82 \%$ for Lagoon (La), 100\% for mangroves (Ma), 90 \% for Plantation (PI), 100\% for Salt pan, $100 \%$ for Sand /sandy beaches, $100 \%$ for Shrub Land, $100 \%$ for Tidal Flats and $100 \%$ for water bodies. 
Table 5

Accuracy Assessment of Land Use and Land Cover_ 2010

\begin{tabular}{|c|c|c|c|c|c|c|c|c|c|c|c|c|}
\hline Class & $\mathrm{BL}$ & $\mathrm{Bu}$ & La & $\mathrm{Ma}$ & PI & Sp & SB & SL & TF & WB & Total & $\begin{array}{l}\text { User's } \\
\text { Accuracy } \\
\text { (\%) }\end{array}$ \\
\hline BL & 9 & 0 & 0 & 0 & 0 & 0 & 1 & 0 & 0 & 0 & 10 & 90 \\
\hline $\mathrm{Bu}$ & 0 & 9 & 0 & 0 & 0 & 0 & 0 & 0 & 0 & 0 & 9 & 100 \\
\hline La & 1 & 0 & 9 & 0 & 1 & 0 & 0 & 0 & 0 & 0 & 11 & 82 \\
\hline $\mathrm{Ma}$ & 0 & 0 & 0 & 10 & 0 & 0 & 0 & 0 & 0 & 0 & 10 & 100 \\
\hline PI & 0 & 1 & 0 & 0 & 9 & 0 & 0 & 0 & 0 & 0 & 10 & 90 \\
\hline Sp & 0 & 0 & 0 & 0 & 0 & 10 & 0 & 0 & 0 & 0 & 10 & 100 \\
\hline SB & 0 & 0 & 1 & 0 & 0 & 0 & 9 & 0 & 0 & 0 & 10 & 90 \\
\hline SL & 0 & 0 & 0 & 0 & 0 & 0 & 0 & 9 & 0 & 0 & 9 & 100 \\
\hline TF & 0 & 0 & 0 & 0 & 0 & 0 & 0 & 0 & 9 & 0 & 9 & 100 \\
\hline WB & 0 & 0 & 0 & 0 & 0 & 0 & 0 & 0 & 0 & 9 & 9 & 100 \\
\hline Total & 10 & 10 & 10 & 10 & 10 & 10 & 10 & 9 & 9 & 9 & 92 & \\
\hline $\begin{array}{l}\text { Producer's } \\
\text { Accuracy (\%) }\end{array}$ & 90 & 90 & 90 & 100 & 90 & 100 & 90 & 100 & 100 & 100 & & \\
\hline \multicolumn{13}{|c|}{ Overall Accuracy $=95 \%$} \\
\hline Kappa coeffici & & & & & & & & & & & & \\
\hline
\end{tabular}

Accuracy assessment (2015) results reveal that in an overall accuracy of $94 \%$, Kappa coefficient $93 \%$ (Table 6). The user's accuracy of $90 \%$ was noticed for Barren Land (BL), $90 \%$ for Built-up Land (Bu), $90 \%$ for Lagoon (La), 100\% for mangroves (Ma), 90 \% for Plantation (PI), 100\% for Salt pan, $100 \%$ for Sand /sandy beaches, $90 \%$ for Shrub Land, $100 \%$ for Tidal Flats and $90 \%$ for water bodies. 
Table 6

Accuracy Assessment of Land Use and Land Cover_ 2015

\begin{tabular}{|c|c|c|c|c|c|c|c|c|c|c|c|c|}
\hline Class & BL & $\mathrm{Bu}$ & La & $\mathrm{Ma}$ & PI & Sp & SB & SL & TF & WB & Total & $\begin{array}{l}\text { User's } \\
\text { Accuracy } \\
\text { (\%) }\end{array}$ \\
\hline BL & 9 & 0 & 0 & 0 & 1 & 0 & 0 & 0 & 0 & 0 & 10 & 90 \\
\hline $\mathrm{Bu}$ & 0 & 9 & 0 & 0 & 0 & 0 & 0 & 0 & 0 & 1 & 10 & 90 \\
\hline La & 0 & 0 & 9 & 0 & 0 & 0 & 1 & 0 & 0 & 0 & 10 & 90 \\
\hline $\mathrm{Ma}$ & 0 & 0 & 0 & 9 & 0 & 0 & 0 & 0 & 0 & 0 & 9 & 100 \\
\hline PI & 0 & 1 & 0 & 0 & 9 & 0 & 0 & 0 & 0 & 0 & 10 & 90 \\
\hline Sp & 0 & 0 & 0 & 0 & 0 & 10 & 0 & 0 & 0 & 0 & 10 & 100 \\
\hline SB & 0 & 0 & 0 & 0 & 0 & 0 & 9 & 0 & 0 & 0 & 9 & 100 \\
\hline SL & 0 & 0 & 1 & 0 & 0 & 0 & 0 & 9 & 0 & 0 & 10 & 90 \\
\hline TF & 0 & 0 & 0 & 0 & 0 & 0 & 0 & 0 & 10 & 0 & 10 & 100 \\
\hline WB & 0 & 0 & 0 & 1 & 0 & 0 & 0 & 0 & 0 & 9 & 10 & 90 \\
\hline Total & 9 & 10 & 10 & 10 & 10 & 10 & 10 & 9 & 10 & 10 & 92 & \\
\hline $\begin{array}{l}\text { Producer's } \\
\text { Accuracy (\%) }\end{array}$ & 100 & 90 & 90 & 90 & 90 & 100 & 90 & 100 & 100 & 90 & & \\
\hline \multicolumn{13}{|c|}{ Overall Accuracy $=94 \%$} \\
\hline Kappa coeffic & & & & & & & & & & & & \\
\hline
\end{tabular}

Accuracy assessment for the year 2020 results in an overall accuracy of $87 \%$, Kappa coefficient $86 \%$ (Table 7). The user's accuracy $100 \%$ was noticed for Barren Land (BL), $91 \%$ for Built-up Land (Bu), $83 \%$ for Lagoon (La), 100\% for mangroves (Ma), $100 \%$ for Plantation (PI), 100\% for Salt pan, $100 \%$ for Sand /sandy beaches, $90 \%$ for Shrub Land, $100 \%$ for Tidal Flats and $100 \%$ for water bodies. 
Table 7

Accuracy Assessment of Land Use and Land Cover_ 2020

\begin{tabular}{|c|c|c|c|c|c|c|c|c|c|c|c|c|}
\hline Class & BL & BU & La & $\mathrm{Ma}$ & $\mathrm{PI}$ & Sp & SB & SL & TF & WB & Total & $\begin{array}{l}\text { User's } \\
\text { Accuracy } \\
\text { (\%) }\end{array}$ \\
\hline BL & 9 & 0 & 0 & 0 & 0 & 0 & 0 & 0 & 0 & 0 & 9 & 100 \\
\hline $\mathrm{Bu}$ & 0 & 10 & 0 & 0 & 1 & 0 & 0 & 0 & 0 & 0 & 11 & 91 \\
\hline La & 1 & 0 & 10 & 0 & 0 & 0 & 1 & 0 & 0 & 0 & 12 & 83 \\
\hline $\mathrm{Ma}$ & 0 & 0 & 0 & 10 & 0 & 0 & 0 & 0 & 0 & 0 & 10 & 100 \\
\hline PI & 0 & 0 & 0 & 0 & 9 & 0 & 0 & 0 & 0 & 0 & 9 & 100 \\
\hline Sp & 0 & 0 & 0 & 0 & 0 & 10 & 0 & 0 & 0 & 0 & 10 & 100 \\
\hline SB & 0 & 0 & 0 & 0 & 0 & 0 & 9 & 0 & 0 & 0 & 9 & 100 \\
\hline SL & 0 & 0 & 0 & 0 & 0 & 0 & 0 & 10 & 0 & 0 & 10 & 100 \\
\hline Tf & 0 & 0 & 0 & 0 & 0 & 0 & 0 & 0 & 10 & 0 & 10 & 100 \\
\hline WB & 0 & 0 & 0 & 0 & 0 & 0 & 0 & 0 & 0 & 10 & 10 & 100 \\
\hline Total & 10 & 10 & 10 & 10 & 10 & 10 & 10 & 10 & 10 & 10 & 97 & \\
\hline $\begin{array}{l}\text { Producer's } \\
\text { Accuracy (\%) }\end{array}$ & 90 & 100 & 100 & 100 & 90 & 100 & 90 & 100 & 100 & 100 & & \\
\hline \multicolumn{13}{|c|}{ Overall Accuracy = $87 \%$} \\
\hline \multicolumn{13}{|c|}{ Kappa coefficient $=86 \%$} \\
\hline
\end{tabular}

Overall accuracy assessment study reveals that $91 \%$ accuracy is matched with the ground for all the years above. That indicates a higher amount of matching. However, producer accuracy for all years of all classes is also above $85 \%$ accuracy. It means during the pixel-based classification, more than $85 \%$ of classes correctly matching with the ground points, and less than $15 \%$ of pixels are incorrectly classified. Hence the land use and land cover results have been verified with an accuracy assessment method.

\subsection{LST Changes between 2000 and 2020}

The land surface temperature was calculated using the thermal band of Landsat satellite data sets from 2000 to 2020 and GIS software. The overall findings show that the highest temperature was noticed in 2000 $(260 \mathrm{C})$, and the lowest temperature was noticed in $2005\left(15^{\circ} \mathrm{C}\right)$. During the year 2000, 2005, 2010, 2015, and 2020 , radiates a maximum temperature of about $30^{\circ} \mathrm{C}, 29^{\circ} \mathrm{C}, 30^{\circ} \mathrm{C}, 30^{\circ} \mathrm{C}$, and $27^{\circ} \mathrm{C}$ respectively (Table 8). The Spatial maps were prepared, and it is shown in Fig. 3 (a-e). The lowest LST (18-220 Celsius) was noticed over the area covered with water bodies such as rivers and lagoons, where the wetness is present in the study area. The highest temperature was recorded mostly on barren land and built up-land. The spatial details of GIS output are graphically shown in (Fig. 4) 
Table 8

Spatial distribution results of Land Surface Temperature (2000-2020)

\begin{tabular}{|llllllllll|}
\hline $\mathbf{2 0 0 0}$ & $\mathbf{2 0 0 5}$ & \multicolumn{3}{c}{$\mathbf{2 0 1 0}$} & $\mathbf{2 0 1 5}$ & \multicolumn{3}{c|}{$\mathbf{2 0 2 0}$} & \\
\hline $\begin{array}{l}\text { Temp } \\
\left({ }^{\circ} \mathrm{C}\right)\end{array}$ & $\begin{array}{l}\text { Area } \\
\left(\mathrm{km}^{2}\right)\end{array}$ & $\begin{array}{l}\text { Temp } \\
\left({ }^{\circ} \mathrm{C}\right)\end{array}$ & $\begin{array}{l}\text { Area } \\
\left(\mathrm{km}^{2}\right)\end{array}$ & $\begin{array}{l}\text { Temp } \\
\left({ }^{\circ} \mathrm{C}\right)\end{array}$ & $\begin{array}{l}\text { Area } \\
\left(\mathbf{k m}^{2}\right)\end{array}$ & $\begin{array}{l}\text { Temp } \\
\left({ }^{\circ} \mathrm{C}\right)\end{array}$ & $\begin{array}{l}\text { Area } \\
\left(\mathbf{k m}^{2}\right)\end{array}$ & $\begin{array}{l}\text { Temp } \\
\left({ }^{\circ} \mathrm{C}\right)\end{array}$ & $\begin{array}{l}\text { Area } \\
\left(\mathrm{km}^{2}\right)\end{array}$ \\
\hline $18-22$ & 33 & $09-10$ & 64 & $17-22$ & 48 & $20-23$ & 79 & $15-16$ & 12 \\
\hline $22-24$ & 37 & $10-14$ & 115 & $22-24$ & 68 & $23-24$ & 114 & $16-19$ & 52 \\
\hline $24-26$ & 96 & $14-16$ & 106 & $24-25$ & 182 & $24-25$ & 81 & $19-22$ & 113 \\
\hline $26-27$ & 164 & $16-21$ & 100 & $25-26$ & 104 & $25-26$ & 111 & $22-24$ & 173 \\
\hline $27-30$ & 137 & $21-29$ & 83 & $26-30$ & 66 & $26-30$ & 85 & $24-27$ & 119 \\
\hline
\end{tabular}

\subsection{Relationship between LULC and LST}

The radiative temperature from the reflecting radiative energy of the earth's surface is known as land surface temperature. The reflected radiance of every feature on the land surface has its characteristics. Therefore, Changes in land use/land cover (LU / LC) impact land surface temperature. The LU / LC of an area tends to alter due to many natural and anthropological variables. As it changes, the local climate of the region will also show variations. Hence, the study considers quantifying the magnitude of the LST based on a regional scale (Norman and Becker 1995).

The Contribution Index $(\mathrm{Cl})$ will vary in between Negative to Positive values. A positive $\mathrm{Cl}$ value indicates the effect of that specific land feature on increasing surface temperature. A negative $\mathrm{Cl}$ value represents the influence of land features to stabilise or decrease the surface temperature.

The $\mathrm{Cl}$ value of Built-up land increased from -0.006 in 2000 to 0.003 in 2020. For the Plantation, $\mathrm{Cl}$ increased from -0.055 in 2000 to -0.020 in 2020. Cl of Barren land decreased from 0.010 in 2000 to -0.117 in 2020. In Sand/Sandy Beaches, Cl decreased from 0.103 in 2000 to 0.088 in 2020. For the waterbodies, $\mathrm{Cl}$ decreased from -0.036 in 2000 to -0.061 in 2020. Cl of Mangroves decreased from 0.003 in 2000 to 0.000 in 2020. For the Saltpan region, $\mathrm{Cl}$ decreased from -0.001 in 2000 to -0.031 in 2020. In the scrubland, $\mathrm{Cl}$ increased from -0.041 in 2000 to -0.005 in 2020 . Cl value of lagoon increased from -0.079 to -0.021 in 2020. In the Tidal flat region, $\mathrm{Cl}$ increased from -0.011 in 2000 to 0.000 in 2020 . In the study area, the Highest positive contribution index $(\mathrm{Cl})$ noted in Sand/ Sandy beaches because it covers a larger area of bare soil and lacks vegetation cover. Similarly, Land Surface Temperature is also high in this region. Those covered by plantation, waterbodies, salt pan, shrubland, lagoon, and Tidal flats negatively contributed. It indicates that vegetation or wetness in these regions makes a stabilising or cooling effect over these regions (Fig. 5 and Table 9). 
Table 9

Contribution Index between LULC and LST

\begin{tabular}{|llllll|}
\hline Classes & $\mathbf{2 0 0 0}$ & $\mathbf{2 0 0 5}$ & $\mathbf{2 0 1 0}$ & $\mathbf{2 0 1 5}$ & $\mathbf{2 0 2 0}$ \\
\hline Built-up Land & -0.006 & 0.104 & -0.023 & 0.019 & 0.003 \\
Plantation & -0.055 & -0.526 & -0.041 & 0.106 & -0.020 \\
Barren land & 0.010 & 0.275 & -0.012 & -0.426 & -0.117 \\
\hline Sand/ Sandy Beaches & 0.103 & -0.225 & 0.010 & 0.270 & 0.088 \\
Water bodies & -0.036 & -0.036 & -0.004 & 0.011 & -0.061 \\
\hline Mangrove & 0.003 & -0.001 & -0.0002 & 0.0002 & 0.000 \\
Saltpan & -0.001 & 0.010 & 0.003 & -0.009 & -0.031 \\
\hline Scrubland & -0.041 & 0.074 & -0.001 & -0.001 & -0.005 \\
\hline lagoon & -0.079 & 0.196 & -0.008 & -0.035 & -0.021 \\
\hline Tidal flat & -0.011 & 0.005 & -0.001 & 0.002 & 0.000 \\
\hline 3.4 Intens & Of Urban Heat Island & & &
\end{tabular}

The study area is between moderate to very strong heat islands. As per the study in $2000,466.2 \mathrm{~km}^{2}(99.6 \%)$ of the total study area is under a Very Strong heat island. In 2005, $169.5 \mathrm{~km}^{2}, 36 \%$ area under Moderate heat island, $139.7 \mathrm{~km}^{2}$ area was strong heat island, $83.4 \mathrm{~km}^{2}$ area very strong heat island and $72.6 \mathrm{~km}^{2}$ area under weak heat island. During 2010, the maximum area of $463.8 \mathrm{~km}^{2}(99.1 \%)$ came under a Very Strong heat island. There was an increase in land surface temperature noted during this year. In $2015,456 \mathrm{~km}^{2}(97 \%)$ came under a Very Strong heat island. In 2020, about $356 \mathrm{~km}^{2}$ (76\%) came under a very strong heat island and $102.1 \mathrm{~km}^{2}$ on a strong heat Island. The overall result is given in Table 10, and the variation is graphically plotted in (Fig. 6). The study reveals that climatic elements such as rainfall, land surface temperature, and construction activities have a significant role in the changes of the Urban heat island. 
Table 10

UHI Affected Area in $\mathrm{km}^{2}$

\begin{tabular}{|llllll|}
\hline Class & $\mathbf{2 0 0 0}$ & $\mathbf{2 0 0 5}$ & $\mathbf{2 0 1 0}$ & $\mathbf{2 0 1 5}$ & $\mathbf{2 0 2 0}$ \\
\cline { 2 - 6 } & Area $\left(\mathrm{km}^{2}\right)$ & Area $\left(\mathrm{km}^{2}\right)$ & Area $\left(\mathrm{km}^{2}\right)$ & Area $\left(\mathrm{km}^{2}\right)$ & Area $\left(\mathrm{km}^{2}\right)$ \\
\hline Green Island & - & - & - & 2.9 & - \\
Very weak heat island & - & 2.7 & - & - & 0.2 \\
\hline Weak heat island & - & 72.6 & - & - & 0.4 \\
\hline Moderate heat island & - & 169.5 & - & - & 8.8 \\
\hline Strong heat island & 1.8 & 139.7 & 4.2 & 9.0 & 102.1 \\
\hline Very Strong heat island & 466.2 & 83.4 & 463.8 & 456.0 & 356.5 \\
\hline Violent heat island & - & - & - & - & - \\
\hline
\end{tabular}

\section{Conclusion}

The impacts of LU change on LST and UHI intensity were determined for the coastal area of Ramanathapuram and its environs in this study. Detailed Land use and Land cover studies have done for about 21 years, starting from 2000 to 2020. Ten land use-land cover classes are observed and classified: Built-up Land, Plantation, Barren land, Sand/ Sandy Beaches, Water bodies, mangroves, Saltpan, Scrubland, lagoon, and Tidal flat. An overall study concludes that Barren land is the dominant feature in the study area. The other predominant land use is Sand/ Sandy Beaches. The third dominant one is Plantations. The residential area mostly dominated in the central part of Rameswaram island. The Accuracy assessment shows that the classified images have more than $85 \%$ accuracy with the ground for all the land use/ landcover classes. The land surface temperature study concludes that the mean temperature was highest in $2000\left(26^{\circ} \mathrm{C}\right)$ and least in $2005\left(15^{\circ} \mathrm{C}\right)$. During the years $2000,2005,2010,2015$, and 2020 , the study area radiates a maximum temperature of about $30^{\circ} \mathrm{C}, 29^{\circ} \mathrm{C}, 30^{\circ} \mathrm{C}, 30^{\circ} \mathrm{C}$, and $27^{\circ} \mathrm{C}$. In a barren land, it indicates about $24^{\circ} \mathrm{C}-27^{\circ} \mathrm{C}$, the highest temperature was found in this region.

The correlation study between land use/land cover (LU / LC) and land surface temperature indicates that both the parameters are related. The changes in land use and land cover makes fluctuations in ground surface temperature. In the study area, the significant contribution of warming comes from Sand/ Sandy beaches due to their wide coverage. Sand/ Sandy Beaches' contribution index has a significant change in $\mathrm{Cl}$ value from 2000 to 2020 . The area covered by plantation, waterbodies, salt pan, shrubland, lagoon, and Tidal flats had a negative contribution

The Urban Heat Island study concludes that area between moderate to very strong Heat Islands. The study concludes that climate elements such as rainfall, terrestrial, surface temperature, and construction activities play a significant role in the island's urban heat changes. 


\section{Declarations}

Acknowledgement, The author, acknowledges the Indian Space Research Organization (ISRO) -Respond Program for this research's financial assistance and National Remote Sensing Centre (NRSC) as well as the Centre for applied geology, The Gandhigram Rural Institute (Deemed to be University).

Author contribution Gurugnanam Balasubramanian: Writing of original draft, formal analysis. Methodology. Glitson Francis Pereira: Software handling and writing of the original draft. Bairavi Swaminathan: Data curation Software handling. Santonu Goswami: Investigation. Saroj Choudhury: writing of review and editing, investigation

Availability of data and material The research depended on Landsat satellite data obtained through the Earth Explorer website, which is open to the public.

Code availability Software: ArcGIS 10.5, Erdas Imagine.

Ethics approval Not applicable.

Consent to participate Not applicable.

Consent to publication Not applicable.

Conflict of interest Authors declares no competing interests.

Funding information: The work is carried out with the funding support from ISRO Respond programme of Govt. of India.

\section{References}

1. Anderson MC, Hain C, Wardlow B, Pimstein A, Mecikalski JR, Kustas WP (2011) Evaluation of drought indices based on thermal remote sensing of evapotranspiration over the continental United States. Journal of Climate v 24(8):2025-2044

2. Anderson MC, Norman JM, Kustas WP, Houborg R, Starks PJ, Agam N (2008) A thermal-based remote sensing technique for routine mapping of land-surface carbon, water and energy fluxes from field to regional scales, v.112. Remote Sensing of Environment, pp 4227-4241

3. Arnfield AJ (2003) Two decades of urban climate research: a review of turbulence, exchanges of energy and water, and the urban heat island. International Journal of Climatology: a Journal of the Royal Meteorological Society 23(1):1-26

4. Bastiaanssen WG, Menenti M, Feddes RA, Holtslag AAM (1998) A remote sensing surface energy balance algorithm for land (SEBAL). 1. Formulation. J Hydrol 212:198-212

5. Buyadi SNA, Mohd WMNW, Misni A (2013) Impact of land use changes on the surface temperature distribution of area surrounding the National Botanic Garden, Shah Alam, v.101. Procedia-Social and Behavioral Sciences, pp 516-525 
6. Barnsley MJ, Moller-Jensen L, Barr SL (2000) Inferring urban land use by spatial and structural pattern recognition. Remote sensing and image analysis. Routledge, pp 115-144

7. Bolund P, Hunhammar S (1999) Ecosystem services in urban areas. Ecological economics 29(2):293301

8. Brunsell NA, Gillies RR (2003) Length scale analysis of surface energy fluxes derived from remote sensing. J Hydrometeorol 4(6):1212-1219

9. Becker F, LI ZL (1990) Towards a local split window method over land surfaces. Remote sensing 11(3):369-393

10. Badarinath KVS, Chand TK, Madhavilatha K, Raghavaswamy V (2005) Studies on urban heat islands using ENVISAT AATSR data. J Indian Soc Remote Sens 33(4):495-501

11. Carlson TN, Gillies RR, Perry EM (1994) A method to make use of thermal infrared temperature and NDVI measurements to infer surface soil water content and fractional vegetation cover. Remote sensing reviews $9(1-2): 161-173$

12. Colding J (2007) 'Ecological land-use complementation for building resilience in urban ecosystems. Landscape urban planning 81(1-2):46-55

13. Coppin PR, Bauer ME (1996) Digital change detection in forest ecosystems with remote sensing imagery. Remote sensing reviews 13(3-4):207-234

14. Chen XL, Zhao HM, Li PX, Yin ZY (2006) Remote sensing image-based analysis of the relationship between urban heat island and land use/cover changes. Remote Sens Environ 104(2):133-146

15. Campbell JB (1987) Introduction to Remote Sensing. The Guilford Press, New York, p 551

16. Dousset B, Gourmelon F, Laaidi K, Zeghnoun A, Giraudet E, Bretin P, Mauri E, Vandentorren S (2011) Satellite monitoring of summer heatwaves in the Paris metropolitan area. Int J Climatol 31(2):313-323

17. Essa W, Verbeiren B, Van Der Kwast J, Van De Voorde T, Batelaan O (2012) Evaluation of the Dis Trad thermal sharpening methodology for urban areas. Int J Appl Earth Obs Geoinf 19:163-172

18. Geist HJ, Lambin EF (2001) What drives tropical deforestation. LUCC Report Series, v.4, pp.116

19. Guzha AC, Rufino MC, Okoth S, Jacobs S, Nóbrega RLB (2018) Impacts of land use and land cover change on surface runoff, discharge, and low flows: Evidence from East Africa. Journal of Hydrology: Regional Studies 15:49-67

20. Galford GL, Mustard JF, Melillo J, Gendrin A, Cerri CC, Cerri CE (2008) Wavelet analysis of MODIS time series to detect expansion and intensification of row-crop agriculture in Brazil. Remote Sens Environ 112(2):576-587

21. Gallo KP, Tarpley JD, McNab AL, Karl TR (1995) Assessment of urban heat islands: a satellite perspective. Atmospheric Research v 37(1-3):37-43

22. Gaston KJ, Warren PH, Thompson K, Smith RM (2005) Urban domestic gardens (IV): the extent of the resource and its associated features. Biodiversity \& Conservation, v.14(14), pp 3327-3349

23. Hathout S (2002) The use of GIS for monitoring and predicting urban growth in East and West St Paul, Winnipeg, Manitoba, Canada. Journal of Environmental Management v 66(3):229-238 
24. Herold M, Gardner ME, Roberts DA (2003) Spectral resolution requirements for mapping urban areas. IEEE Transactions on Geoscience remote sensing 41(9):1907-1919

25. Hansen J, Ruedy R, Sato M, Lo K (2010) Global surface temperature change. Rev Geophys 48(4):RG4004

26. Hain CR, Crow WT, Mecikalski JR, Anderson MC, Holmes T (2011) An intercomparison of available soil moisture estimates from thermal infrared and passive microwave remote sensing and land surface modelling. J. Geophys. Res: Atmos, v.116(D15)

27. Jin S, Yang L, Zhu Z, Homer C (2017) A land cover change detection and classification protocol for updating Alaska NLCD 2001 to 2011, v.195. Remote Sensing of Environment, pp 44-55

28. Jensen JR, Rutchey K, Koch MS, Narumalani S (1995) Inland wetland change detection in the Everglades Water Conservation Area 2A using a time series of normalised remotely sensed data. Photogrammetric Engineering Remote Sensing V 61(2):199-209

29. Jiménez-Muñoz JC, Sobrino JA (2003) A generalised single-channel method for retrieving land surface temperature from remote sensing data. Journal of Geophysical Research v 108(D22):4688-4695

30. Kiruki HM, van der Zanden EH, MALEK Ž, VERBURG PH (2017) Land cover change and woodland degradation in a charcoal producing semi-arid area in Kenya. Land degradation \& development, v.28(2), pp 472-481

31. Karnieli A, Agam N, Pinker RT, Anderson M, Imhoff ML, Gutman GG, Panov N, Goldberg A (2010) Use of NDVI and land surface temperature for drought assessment: Merits and limitations. J Clim 23(3):618633

32. Kalma JD, Mcvicar TR, Mccabe MF (2008) Estimating land surface evaporation: A review of methods using remotely sensed surface temperature data. Surveys in Geophysics v 29(4-5):421-469

33. Kumar KS, Bhaskar PU, Padmakumari K (2012) Estimation of land surface temperature to study urban heat island effect using LANDSAT ETM + image. International Journal of Engineering Science Technology 4(2):771-778

34. Kogan FN (2001) Operational space technology for global vegetation assessment. Bulletin of the American meteorological society 82(9):1949-1964

35. Kiefer RW, Lillesand TM (1994) Remote sensing and image interpretation. University of Gajah Mada University Press. Bulaksumur, Yogyakarta

36. Kühn I, Klotz S (2006) Urbanization and homogenisation-comparing the floras of urban and rural areas in Germany. Biol Cons 127(3):292-300

37. Kustas W, Anderson M (2009) Advances in thermal infrared remote sensing for land surface modelling. Agric For Meteorol 149(12):2071-2081

38. Kalma JD, Mcvicar TR, Mccabe MF (2008) Estimating land surface evaporation: A review of methods using remotely sensed surface temperature data. Surveys in Geophysics v 29(4-5):421-469

39. Kogan FN (2001) Operational space technology for global vegetation assessment. Bulletin of the American meteorological society 82(9):1949-1964 
40. Lambin EF, Meyfroidt P (2011) Global land use change, economic globalisation, and the looming land scarcity. Proceedings of the National Academy of Sciences, v.108(9), pp.3465-3472

41. Lambin EF (1999) Monitoring forest degradation in tropical regions by remote sensing: some methodological issues. Global Ecology biogeography 8(3-4):191-198

42. Lambin EF, Geist HJ, Lepers E (2003) Dynamics of land-use and land-cover change in tropical regions. Annual review of environment resources 28(1):205-241

43. Lambin EF, Rounsevell MDA, Geist HJ (2000) Are agricultural land-use models able to predict changes in land-use intensity? Agriculture, Ecosystems \& Environment, v.82(1-3), pp 321-331

44. Lv Z, Liu T, Wan Y, Benediktsson JA, Zhang X (2018) Post-processing approach for refining raw land cover change detection of very high-resolution remote sensing images. Remote sensing, v.10(3), pp.472

45. Luvall JC, Quattrochi DA, Rickman DL, Estes MG Jr (2015a) Urban heat islands. In: North, G.R.(Editor-inchief), Pyle, J., Zhang, F. (Eds.), Encyclopedia of Atmospheric Sciences, second ed, Elsevier, v.1, pp.310318. ISBN 9780123822253

46. Mallick J, Rahman A, Singh CK (2013) Modeling urban heat islands in heterogeneous land surface and its correlation with impervious surface area by using night-time ASTER satellite data in highly urbanising city, Delhi-India. Adv Space Res 52(4):639-655

47. Nithu Raj B, Gurugnanam V, Sudhakar PG, Francis, Estuarine shoreline change analysis along the Ennore river mouth, southeast coast of India, using digital shoreline analysis system, Geodesy and Geodynamics, Volume 10, Issue 3,2019, Pages 205-212

48. Nichol JE (1996) High-resolution surface temperature patterns related to urban morphology in a tropical city: A satellite-based study. Journal of applied meteorology 35(1):135-146

49. Norman JM, Becker F (1995) Terminology in thermal infrared remote sensing of natural surfaces. Agricultural Forest Meteorology v 77(3-4):153-166

50. Owen TW, Carlson TN, Gillies RR (1998) An assessment of satellite remotely-sensed land cover parameters in quantitatively describing the climatic effect of urbanisation. International journal of remote sensing 19(9):1663-1681

51. Pauleit S, Duhme F (2000) Assessing the environmental performance of land cover types for urban planning. Landscape urban planning 52(1):1-20

52. Pandey B, Seto KC (2015) Urbanisation and agricultural land loss in India: Comparing satellite estimates with census data. Journal of environmental management 148:53-66

53. Phiri D, Morgenroth J (2017) Developments in Landsat land cover classification methods: A review. Remote sensing, v.9(9), pp.967

54. Rao P, Puntambekar K (2011) Evaluating the Urban Green Space benefits and functions at macro, meso and micro level: case of Bhopal City. B BR, v.377, pp.31 - 16

55. Rahman A, Khan J, Ali I, Khan TA, Alam SD (2013) Dynamics of Land Use/Land Cover Changes in Ballia District, Using Landsat TM Data. J Remote Sens GIS 4(1):29-35

56. Rahman A (2007) Application of remote sensing and GIS technique for urban environmental management and sustainable development of Delhi, India. In: Applied remote sensing for urban 
planning, governance and sustainability. Springer, Berlin, pp 165-197

57. Rahman A, Kumar S, Fazal S, Siddiqui MA (2012) Assessment of land use/land cover change in the North-West District of Delhi using remote sensing and GIS techniques. J Indian Soc Remote Sens 40(4):689-697

58. Riebsame WE, MEYER WB, TURNER BL (1994) Modeling land use and cover as part of global environmental change. Climatic change 28(1-2):45-64

59. Rajeshwari A, Mani ND (2014) Estimation of land surface temperature of Dindigul district using Landsat 8 data. International Journal of Research in Engineering Technology 3(5):122-126

60. Rai SC, Sharma E, Sundriyal RC (1994) Conservation in the Sikkim Himalaya: traditional knowledge and land-use of the Mamlay watershed. Environ Conserv 21(1):30-34

61. Read JM, Lam NSN (2002) Spatial methods for characterising land cover and detecting land-cover changes for the tropics. Int J Remote Sens 23(12):2457-2474

62. Seto KC, Woodcock CE, Song C, Huang X, Lu J, Kaufmann RK (2002) Monitoring land-use change in the Pearl River Delta using Landsat TM. Int J Remote Sens 23(10):1985-2004

63. Sekertekin A, Marangoz am, Akcin H (2017) Pixel based classification analysis of land use land cover using sentinel-2 and landsat-8 data. Int Arch Photogrammetry Remote Sens Spatial Information Sci vXLII-4/W6, 91-93. 4th International GeoAdvances Workshop, 14-15 October 2017, Safranbolu, Karabuk, Turkey

64. Senanayake IP, Welivitiya WDDP, Nadeeka PM (2013) Assessment of green space requirement and site analysis in Colombo, Sri Lanka-a remote sensing and GIS approach. International Journal of Scientific Engineering Research 4(12):29-34

65. Su Z (2002) The Surface Energy Balance System (SEBS) for estimation of turbulent heat fluxes. Hydrology earth system sciences 6(1):85-99

66. Shahmohamadi P, Che-Ani Al, Maulud KNA, Tawil NM, Abdullah NAG (2011) The impact of anthropogenic heat on formation of urban heat island and energy consumption balance. Urban Studies Research

67. Saadat H, Adamowski J, Bonnell R, Sharifi F, Namdar M, Ale-Ebrahim S (2011) Land use and land cover classification over a large area in Iran based on single date analysis of satellite imagery. ISPRS Journal of Photogrammetry Remote Sensing 66(5):608-619

68. Schneider P, Hook SJ (2010) Space observations of inland water bodies show rapid surface warming since 1985. Geophys. Res. Lett. 37

69. Thomas IL, Benning VM, CHING NP (1987) Classification of remotely sensed images, p.77

70. Tso, BR.A.N.DT, Olsen RC (2005) Combining spectral and spatial information into hidden Markov models for unsupervised image classification. International Journal of Remote Sensing v 26(10):21132133

71. Velsamy S, Balasubramaniyan G, Swaminathan B et al (2020) Multi-decadal shoreline change analysis in coast of Thiruchendur Taluk, Thoothukudi district, Tamil Nadu, India, using remote sensing and DSAS techniques. Arab J Geosci 13:838 
72. Voogt JA, Oke TR (2003) Thermal remote sensing of urban climates. Remote Sens Environ 86(3):370384

73. Weng Q, LU D, Schubring J (2004) Estimation of land surface temperature-vegetation abundance relationship for urban heat island studies. Remote Sens Environ 89(4):467-483

74. Woodcock CE, Macomber SA, Pax-Lenney M, COHEN WB (2001) Large area monitoring of temperate forest change using Landsat data: Generalisation across sensors, time and space. Remote Sensing of Environment v 78(1-2):194-203

75. Woodcock CE, Strahler AH (1987) The factor of scale in remote sensing. Remote Sens Environ 21(3):311-332

76. Wu T, Luo J, Fang J, Ma J, Song X (2017) Unsupervised object-based change detection via a Weibull mixture model-based binarisation for high-resolution remote sensing images. IEEE Geosci Remote Sens Lett 15(1):63-67

77. Xu Ly, Xie XD, Li S (2013) Correlation analysis of the urban heat island effect and the spatial and temporal distribution of atmospheric particulates using TM images in Beijing, v.178. Elsevier, Environmental Pollution, pp 102-114

78. Yang C, He X, Yan F, Yu L, Yang BU,K, Chang J, L. and Zhang S (2017) Mapping the influence of land use/land cover changes on the urban heat island effect-A case study of Changchun, China. Sustainability, v.9(2), p.312

79. Yuan F, Sawaya KE, Loeffelholz B, Bauer ME (2005) Land cover classification and change analysis of the Twin Cities (Minnesota) Metropolitan Area by multitemporal Landsat remote sensing. Remote Sens Environ 98:317-328

80. Zhang Y, Yiyun C, Qing D, Jiang P (2012) Study on urban heat island effect based on Normalized Difference Vegetated Index: A case study of Wuhan City, v.13. Procedia environmental sciences, pp 574-581

81. Zhang J, Wang Y (2008) Study of the relationships between the spatial extent of surface urban heat islands and urban characteristic factors based on Landsat ETM + data. Sensors 8(11):7453-7468

\section{Figures}




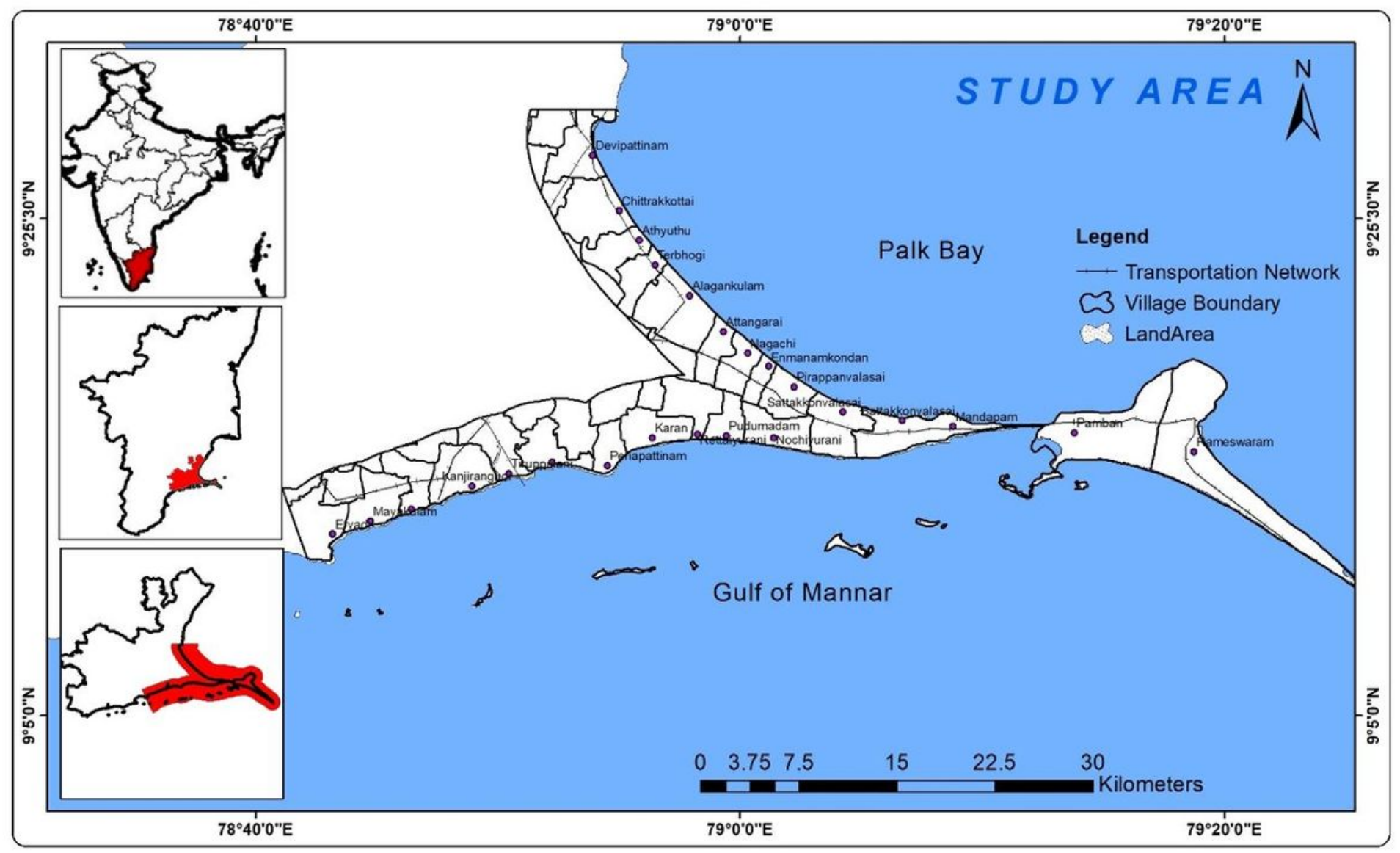

Figure 1

Study Area 


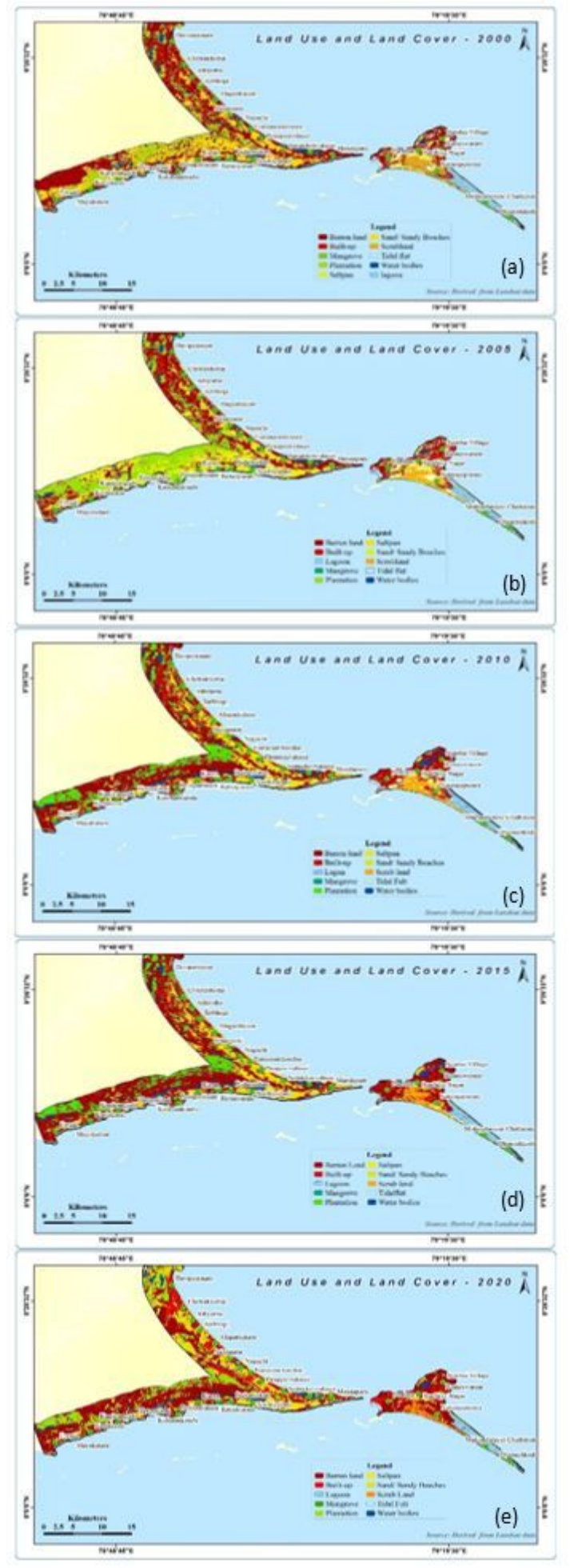

Figure 2

(a - e) Spatial distribution of Landuse/Landcover (2000-2020) 


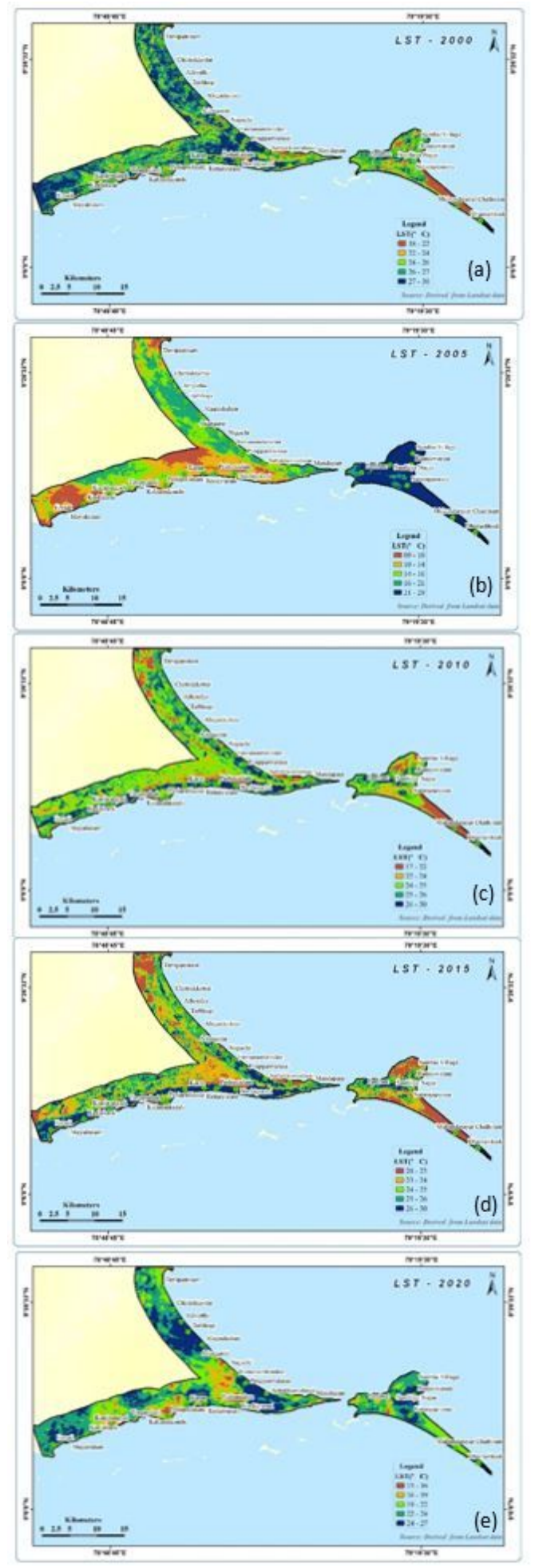

Figure 3

(a - e) Spatial distribution of Land Surface Temperature (2000-2020) 


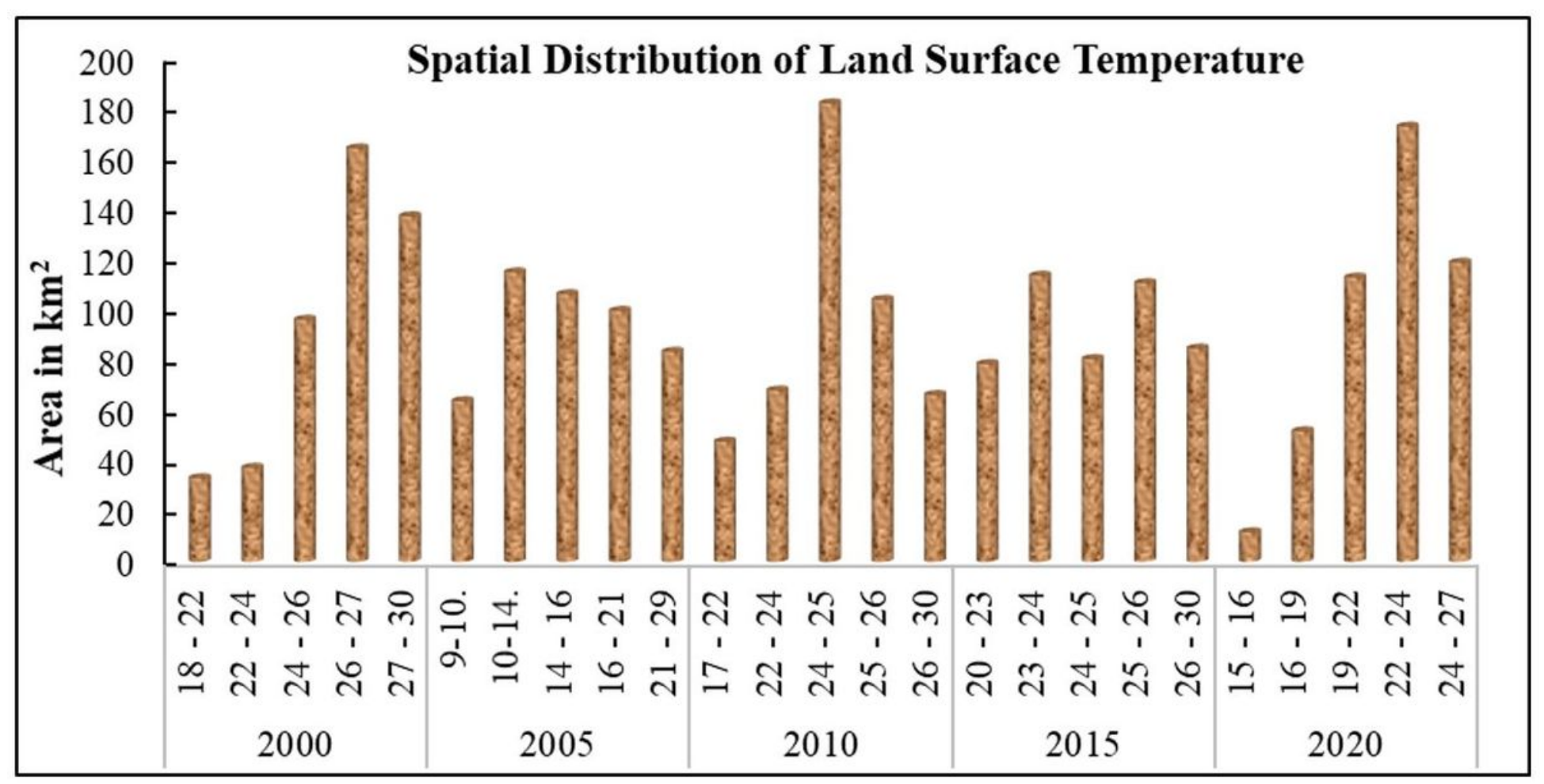

Figure 4

Spatial distribution of Landuse/ Landcover Vs Year 


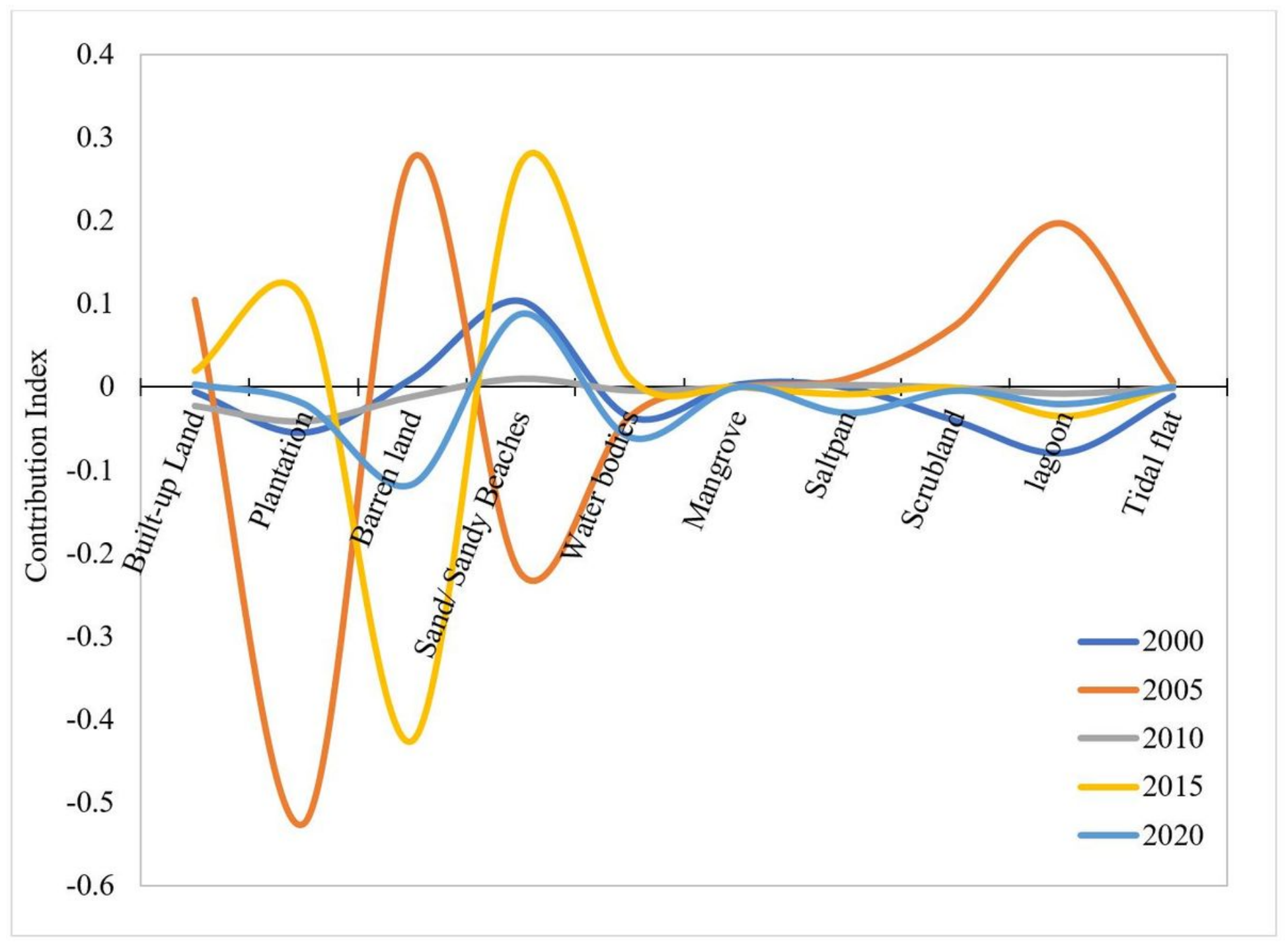

Figure 5

Contribution of LULC types and their changes to LST 




\section{Figure 6}

Urban Heat Island variations in per cent 